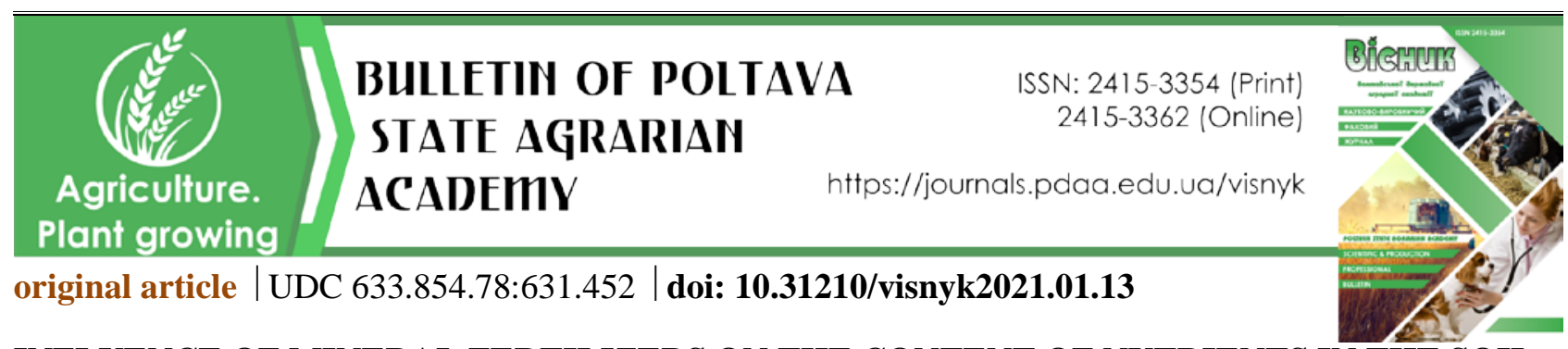

INFLUENCE OF MINERAL FERTILIZERS ON THE CONTENT OF NUTRIENTS IN THE SOIL AND THE YIELD OF SUNFLOWER HYBRIDS OF DIFFERENT MATURITY GROUPS

\author{
V. V. Hanhur* \\ O. O. Kosminskyi \\ ORCID (D) 0000-0002-5619-492X \\ O. V. Mishchenko \\ Poltava State Agrarian Academy, 1/3, Skovorody str., Poltava, 36003, Ukraine \\ *Corresponding author \\ E-mail: volodimirgangur@gmail.com
}

How to Cite

Hanhur, V. V., Kosminskyi, O. O., \& Mishchenko, O. V. (2021). Influence of mineral fertilizers on the content of nutrients in the soil and the yield of sunflower hybrids of different maturity groups. Bulletin of Poltava State Agrarian Academy, (1), 116-121. doi: 10.31210/visnyk2021.01.13

In agrarian production of Ukraine, the main oil-bearing crop is sunflower (Helianthus annuus L.), the volumes of gross seed production of which increase almost every year. However, this positive tendency has been achieved mainly due to expanding the sown areas, rather than a significant yield increase. Therefore, it is important to deepen research aimed at increasing the productivity and improving crop quality. The aim of the study was to determine the effect of different fertilizer rates on soil nutrient content and the productivity of sunflower hybrids of different maturity groups. During field experiment at Poltava State Agricultural Experimental Station named after M.I. Vavilov in 2018-2020, it has been found that during sunflower hybrids cultivation, the highest content of nitrogen, which is easily hydrolyzed, was observed at $N_{40} P_{60} K_{60}$ combined mineral fertilizer application. A decrease in nitrogen content in the soil at applying the maximum dose of $N_{60} P_{80}$ fertilizer was observed relative to using low and medium doses. Most of labile phosphorus was contained in the arable soil layer while cultivating Oreol hybrid at the background $N_{30} P_{40}$, Cadet hybrid $-N_{40} P_{60} K_{60}$, and Drive hybrid $N_{40} P_{60}$. It has been found out that the highest potassium content in the soil was at applying $N_{40} P_{60} K_{60}$, or it was higher, as compared with the variant without fertilizers for maturity groups of hybrids - 21.6; 36.0; $44.3 \mathrm{mg} / \mathrm{kg}$ of soil, respectively. According to the research results, it has been revealed that in Oreol hybrid the increase in seed yield after using mineral fertilizers, made $0.15-0.28$ t/ha or $4.8-8.9 \%$ in comparison with the control. The yield of Cadet and Drive hybrids at the background of fertilization was higher as compared with the variant without fertilizers by $0.25-0.30$ t/ha or $7.9-9.5 \%$ and $0.10-0.23$ t/ha or 3.0-6.9\%, respectively. The earlymaturing Oreol hybrid provided the maximum seed yield of 3.41 tha at applying $N_{60} P_{80}$. It has been registered that the mid-early Cadet hybrid reacted the least to various fertilization backgrounds. The difference between the experimental variants in terms of seed yield made only 0.02-0.05 t/ha. The highest seed yield of Drive hybrid - 3.58 t/ha was obtained against the background of $N_{60} P_{80}$.

Key words: sunflower (Helianthus annuus L.), hybrids, soil nutrient schedule, nitrogen, phosphorus, potassium, yield.

\title{
ВПЛИВ МІНЕРАЛЬНИХ ДОБРИВ НА ВМІСТ ПОЖИВНИХ РЕЧОВИН У ГРУНТІ ТА УРОЖАЙНІСТЬ ГІБРИДІВ СОНЯШНИКУ РІЗНИХ ГРУП СТИГЛОСТІ
}

\author{
В. В. Гангур, О. О. Космінський, О. В. Міщенко \\ Полтавська державна аграрна академія, м. Полтава, Україна
}

В аграрному виробництві Украӥни головною олійною культурою є соняшник (Helianthus annuиs L.), обсяги валового виробництва насіння якої практично щорічно зростають. Метою досліджень було 


\section{СІЛЬСЬКЕ ГОСПОДАРСТВО. РОСЛИННИЦТВО}

з'ясувати вплив різного рівня удобрення на вміст поживних речовин у трунті та продуктивність гібридів соняшнику різних груп стиглості. В умовах польового досліду на Полтавській державній сільськогосподарській дослідній станиї імені М. І. Вавилова впродовж 2018-2020 рр. виявлено, щзо у разі вирощування гібридів соняшнику найбільший вміст азоту, що легко гідролізується, спостерігається y разі внесення повного мінерального удобрення $N_{40} P_{60} K_{60}$. Встановлено, щуо у разі внесення максимальної дози добрив $N_{60} P_{80}$, виявлено зменшення вмісту азоту у трунті відносно застосування низьких та середніх доз. Найбільше рухомого фосфору містилося в орному шарі трунту у разі вирошування гібриду Ореол на фоні $N_{30} P_{40}$, гібриду Кадет $-N_{40} P_{60} K_{60}$, а гібриду Драйв - $N_{40} P_{60}$. Виявлено, щяо найбільшим вміст калію у трунті був у разі внесення $N_{40} P_{60} K_{60}$, або був вищим порівняно з варіантом без добрив за групами стиглості гібридів, відповідно на 21,6; 36,0; 44,3 мг/кг трунту. 3а результатами досліджень виявлено, що у гібрида Ореол приріст урожайності насіння від застосування мінеральних добрив порівняно з контролем становив 0,15-0,28 $\mathrm{m} / 2$ а або 4,8-8,9\%. Урожайність гібридів Кадет $і$ Драйв на фоні добрив була вищою порівняно з варіантом без добрив, відповідно на 0,25-0,30 m/2а або 7,9-9,5 \% і 0,10-0,23 m/2а або 3,0-6,9\%. Ранньостиглий гібрид Ореол забезпечив максимальну урожайність насіння $3,41 \mathrm{~m} / 2$ в в разі внесення $N_{60} P_{80}$. Виявлено, щзо середньоранній гібрид Кадет найменше реагував на різні фони удобрення. Різниия між варіантами досліду за урожайністю насіння становила лише 0,02-0,05 m/2a. Найвищу врожайність насіння гібриду Драйв 3,58 m/2a одержано на фоні $N_{60} P_{80}$.

Ключові слова: соняшник, гібриди, поживний режим трунту, азот, фосфор, калій, урожайність.

\section{Вступ}

У сільськогосподарському виробництві України соняшник (Helianthus annuus L.) є важливою i найбільш поширеною олійною культурою. Впродовж останніх десятирічь спостерігається позитивна динаміка щодо валового виробництва насіння культури. Однак аналіз складників зростання валових обсягів виробництва насіння цієї олійної культури свідчить, що воно відбувається переважно внаслідок збільшення площі посіву, ніж від підвищення врожайності. Тому, зважаючи на вищезазначене, актуальним є розроблення та впровадження технологічних заходів, які забезпечать підвищення, стабілізацію продуктивності і покращення якісних показників врожаю.

В умовах Лівобережного Лісостепу України рівень врожайності насіння соняшнику формується через вплив та взаємодію багатьох чинників, серед яких важливим $є$ забезпеченість грунту елементами живлення в обсягах достатніх для оптимального росту і розвитку рослин $[1,7,9,14]$.

Гібриди соняшнику нового покоління мають високий генетично обумовлений потенціал продуктивності, який може забезпечувати формування урожайності насіння на рівні $3,5-5,5$ т/га, за вмісту олії (49-52 \%). Однак в умовах виробництва реалізація максимального потенціалу продуктивності рослин соняшнику можлива лише за дотримання усіх елементів технології та достатнього іiі ресурсного забезпечення $[17,19]$. Серед технологічних прийомів, спрямованих на підвищення врожайності соняшнику, важливу роль відіграє вибір оптимальних норм внесення добрив та покращення умов живлення шляхом підживлення мікроелементами у критичні періоди розвитку культури $[2,3]$.

Створення оптимального фону живлення $\epsilon$ важливим елементом у технології вирощування соняшнику. Внесенням добрив регулюється вміст у грунті доступних рослинам елементів мінерального живлення. Покращання умов грунтового живлення позитивно впливає на інтенсивність та ефективність фотосинтетичних процесів, забезпечує оптимальний ріст і розвиток рослин, формування структурних елементів врожаю та якісних показників насіння $[20,8,10]$.

Під час досліджень в умовах недостатнього зволоження Південного Степу України виявлено, що покращення умов мінерального живлення соняшнику у разі використання різних норм добрив забезпечує збільшення основних показників росту і розвитку рослин і врожайності гібриду Персей на 21,4-30,9 \% [5].

За експериментальними даними Інституту сільського господарства Степу НААН встановлено, що використання азотних добрив сумісно 3 фосфорними та калійними $\mathrm{N}_{40} \mathrm{P}_{40} \mathrm{~K}_{40}+$ побічна продукція та $\mathrm{N}_{40} \mathrm{P}_{40} \mathrm{~K}_{40}$ забезпечує поліпшення поживного режиму грунту та формування сприятливіших умов для росту й розвитку рослин соняшнику [12]. За результатами досліджень, одержаних в умовах Лівобережного Лісостепу України, відзначено, що найвищу урожайність насіння гібридів соняшнику різних груп стиглості було одержано на фоні внесення мінеральних добрив у дозі $\mathrm{N}_{60} \mathrm{P}_{90}$ [15]. Внесення різних доз мінеральних добрив сприяє збільшенню врожайності гібридів соняшника на 0,16-0,43 т/га [11, 18]. 


\section{СІЛЬСЬКЕ ГОСПОДАРСТВО. РОСЛИННИЦТВО}

В умовах Правобережного Лісостепу норма мінеральних добрив $\mathrm{N}_{40} \mathrm{P}_{40} \mathrm{~K}_{60}$ забезпечила зростання врожайності гібриду соняшнику Талса на 53 \%, Пронто та Голден - 58 \%, а ії подвоєння сприяло збільшенню врожайності насіння гібридів порівняно з контролем, відповідно, на 75, 73 та 81 \% [13].

Аналіз літературних джерел свідчить про різні погляди науковців щодо оптимальної норми та ефективності застосування мінеральних добрив у технології вирощування соняшнику, тому це питання потребує більш системного і поглибленого вивчення, зокрема в умовах зони нестійкого зволоження Лівобережного Лісостепу України.

Мета досліджень - з'ясувати вплив різного рівня удобрення на вміст поживних речовин у грунті та продуктивність гібридів соняшнику різних груп стиглості.

Завдання дослідження: вивчити вплив різних норм мінеральних добрив на зміну режиму живлення посівів соняшнику; дослідити вплив системи удобрення на урожайність насіння гібридів соняшнику із різною тривалістю періоду вегетації.

\section{Матеріали і методи досліджень}

Дослідження проводили на дослідному полі Полтавської державної сільськогосподарської дослідної станції імені М. І. Вавилова в тимчасовому польовому досліді.

Грунт дослідної ділянки характеризується такими агрохімічними показниками: вміст гумусу в горизонті 0-20 см становить 3,4\%. Реакція грунтового розчину слабокисла, $\mathrm{pH}$ сольової витяжки 5,9. В орному шарі міститься 6,15 мг азоту, що гідролізується (за Тюріним і Кононовою), 17,1 мг рухомого фосфору (за Чириковим), 21,3 мг на 100 г грунту калію (за Масловою). Дослід двофакторний, включав вивчення різних доз мінеральних добрив (фактор А) та реакцію гібридів різних груп стиглості на фони живлення (фактор В)

Повторність варіантів досліду триразова. Розміщення варіантів і повторень - рендомізоване. Пло-

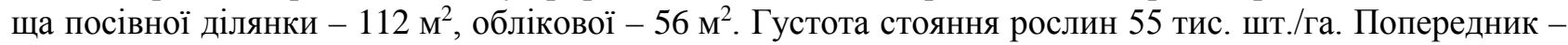
пшениця озима. Технологія вирощування культури загальноприйнята для агроформувань регіону, за винятком елементів, що вивчали. Згідно 3 програмою досліджень були проведені такі обліки та спостереження.

Грунтові зразки для визначення вмісту поживних речовин відбирали на глибину 0-30 см перед внесенням добрив та у фазу настання фізіологічної стиглості рослин. У відібраних зразках визначали: вміст азоту, що легко гідролізується за Корнфілдом; вміст рухомого фосфору та обмінного калію за Чириковим [6]. Збирання врожаю проводили суцільно з облікової площі ділянки. Урожайність насіння приведено в умовах стандартної вологості (8 \%) і 100 \% чистоти.

\section{Результати досліджень та їх обговорення}

Соняшник, маючи потужну кореневу систему і надземну масу, має високі вимоги до забезпеченості грунту доступними формами поживних речовин. Рівень використання елементів живлення із грунту залежить від біологічних особливостей гібридів, тривалості періоду вегетації, асиміляційної активності листя, типу грунту та вмісту в ньому поживних речовин у доступній для рослин формі, гідротермічних умов.

За результатами досліджень виявлено, що внесення різних доз мінеральних добрив сприяло збільшенню вмісту елементів живлення в орному шарі грунту (0-30 см) порівняно з варіантом без внесення добрив (табл. 1). Так, за вирощування гібридів соняшнику найбільший вміст азоту, що легко гідролізується, виявлено в разі внесення повного мінерального удобрення $\mathrm{N}_{40} \mathrm{P}_{60} \mathrm{~K}_{60}$. Порівняно 3 контролем вміст цього елементу живлення був вищим на 12,1-24,4 мг/кг грунту. У разі внесення під соняшник різних доз азотно-фосфорних добрив вміст азоту у грунті також перевищував контроль, однак різниця між варіантами за цим показником була менш вираженою. Важливо зазначити, що на час збирання гібридів соняшнику в разі внесення максимальної кількості мінеральних добрив $\mathrm{N}_{60} \mathrm{P}_{80}$ виявлено зменшення вмісту азоту у грунті відносно застосування низьких та середніх доз. На нашу думку, це пов'язано з кращими умовами живлення для рослин соняшнику на цьому варіанті удобрення та збільшенням витрат азоту на формування елементів структури врожаю. Таку ж тенденцію спостерігали і за вмістом рухомого фосфору під час вирощування ранньостиглого гібриду Ореол, де найвищий вміст фосфору у грунті спостерігали за умови внесення мінімальної дози $\mathrm{N}_{30} \mathrm{P}_{40}$, а в разі збільшення дози добрив вміст його зменшувався. У разі вирощування середньораннього гібриду Кадет найбільше рухомого фосфору містилося в орному шарі грунту за умови внесення $\mathrm{N}_{40} \mathrm{P}_{60} \mathrm{~K}_{60}$. Також 


\section{СІЛЬСЬКЕ ГОСПОДАРСТВО. РОСЛИННИЦТВО}

вищий вміст фосфору відзначено у разі вирощування середньостиглого гібриду Драйв на фоні $\mathrm{N}_{40} \mathrm{P}_{60}$. Внесення азотно-фосфорних добрив сприяло збільшенню вмісту у грунті обмінного калію. За умови вирощування ранньостиглого гібриду Ореол підвищення вмісту обмінного калію порівняно 3 контролем становило 3,8-12,5, середньораннього Кадет - на 8,1-14,5, середньостиглого Драйв - на 16,523,7 мг/кг грунту. Найбільшим вміст калію у грунті був у разі внесення $\mathrm{N}_{40} \mathrm{P}_{60} \mathrm{~K}_{60}$, або був вищим порівняно $з$ варіантом без добрив за групами стиглості гібридів, відповідно, на 21,6; 36,0; 44,3 мг/кг грунту.

\section{1. Вміст поживних речовин у 0-30 см шарі трунту на час збирання гібридів соняшнику}

(середне 2018-2020 рр.)

\begin{tabular}{|c|c|c|c|}
\hline Варіанти удобрення & $\mathrm{NO}_{3}, \mathrm{M \Gamma} / \mathrm{К} \Gamma$ & $\mathrm{P}_{2} \mathrm{O}_{5}, \mathrm{M \Gamma} / \mathrm{K} \Gamma$ & $\mathrm{K}_{2} \mathrm{O}, \mathrm{мг} / \mathrm{Кг}$ \\
\hline \multicolumn{4}{|c|}{ Ореол } \\
\hline Без добрив & 123,9 & 84,5 & 134,7 \\
\hline $\mathrm{N}_{30} \mathrm{P}_{40}$ & 129,5 & 99,4 & 146,8 \\
\hline $\mathrm{N}_{40} \mathrm{P}_{60}$ & 137,0 & 94,9 & 138,5 \\
\hline $\mathrm{N}_{60} \mathrm{P}_{80}$ & 132,4 & 93,1 & 147,2 \\
\hline $\mathrm{N}_{40} \mathrm{P}_{60} \mathrm{~K}_{60}$ & 148,3 & 94,6 & 156,3 \\
\hline \multicolumn{4}{|c|}{ Кадет } \\
\hline Без добрив & 123,9 & 82,3 & 122,9 \\
\hline $\mathrm{N}_{30} \mathrm{P}_{40}$ & 139,1 & 95,2 & 137,4 \\
\hline $\mathrm{N}_{40} \mathrm{P}_{60}$ & 141,1 & 97,2 & 132,6 \\
\hline $\mathrm{N}_{60} \mathrm{P}_{80}$ & 131,9 & 93,9 & 131,0 \\
\hline $\mathrm{N}_{40} \mathrm{P}_{60} \mathrm{~K}_{60}$ & 139,5 & 103,8 & 158,9 \\
\hline \multicolumn{4}{|c|}{ Драйв } \\
\hline Без добрив & 128,2 & 82,0 & 128,6 \\
\hline $\mathrm{N}_{30} \mathrm{P}_{40}$ & 132,6 & 93,9 & 145,1 \\
\hline $\mathrm{N}_{40} \mathrm{P}_{60}$ & 137,2 & 102,7 & 152,3 \\
\hline $\mathrm{N}_{60} \mathrm{P}_{80}$ & 130,4 & 93,4 & 149,2 \\
\hline $\mathrm{N}_{40} \mathrm{P}_{60} \mathrm{~K}_{60}$ & 140,3 & 99,6 & 172,9 \\
\hline
\end{tabular}

Поліпшення поживного режиму грунту та створення більш сприятливих умов для росту й розвитку рослин соняшнику внаслідок застосування азотних добрив у поєднанні з фосфорними та калійними $\mathrm{N}_{40} \mathrm{P}_{40} \mathrm{~K}_{40}+$ побічна продукція попередника та $\mathrm{N}_{40} \mathrm{P}_{40} \mathrm{~K}_{40}$ відзначено в дослідженнях проведених у Правобережному Степу України [12].

Результати проведених досліджень свідчать про різний ступінь впливу мінеральних добрив на формування рівня насіннєвої продуктивності гібридів соняшнику (табл. 2). Варто зазначити, що за даними дисперсійного аналізу істотним $є$ приріст урожайності насіння гібридів соняшнику на варіантах iз внесенням добрив порівняно з контролем. Так, у гібрида Ореол приріст урожайності насіння від застосування мінеральних добрив становив $0,15-0,28$ т/га або 4,8-8,9\%. Урожайність гібридів Кадет і Драйв на фоні добрив була вищою порівняно з варіантом без добрив, відповідно, на 0,25-0,30 т/га або 7,9-9,5 \% і 0,10-0,23 т/га або 3,0-6,9\%. Результати досліджень свідчать, що ранньостиглий гібрид Ореол забезпечив максимальну урожайність насіння 3,41 т/га у разі внесення мінеральних добрив у дозі $\mathrm{N}_{60} \mathrm{P}_{80}$. Важливо зазначити, що в середньораннього гібрида Кадет найменш вираженою $є$ реакція на різні фони удобрення. Урожайність насіння гібриду у разі внесення різних доз добрив становила 3,40-3,45 т/га, тобто різниця між варіантами досліду за цим показником становила лише 0,02-0,05 т/га. Що стосується середньостиглого гібрида Драйв, то спостерігаємо найменший приріст урожайності насіння від внесення добрив, порівняно з гібридами інших груп стиглості. Однак загалом цей гібрид соняшнику характеризувався найвищим рівнем продуктивності та переважав за цим показником ранньостиглий і середньоранній гібрид у середньому за варіантами застосування мінеральних добрив, відповідно на 0,13 і 0,05 т/га. Найвищу урожайність насіння цього гібриду соняшнику 3,58 т/га одержано у разі внесення азотно-фосфорних мінеральних добрив у дозі $\mathrm{N}_{60} \mathrm{P}_{80}$. Дослідження свідчать, що додавання до азотно-фосфорних ще й калійних мінеральних добрив не забезпечувало 


\section{СІЛЬСЬКЕ ГОСПОДАРСТВО. РОСЛИННИЦТВО}

істотного приросту врожайності насіння гібридів соняшнику порівняно лише із внесенням різних доз азотно-фосфорних добрив.

2. Урожайність гібридів соняшнику залежно доз мінеральних добрив (середне за 2018-2020 рр.)

\begin{tabular}{|c|c|c|c|}
\hline \multirow{2}{*}{ Дози добрив, кг/га д. $\mathrm{p.}$} & \multicolumn{3}{|c|}{ Урожайність, т/га } \\
\cline { 2 - 4 } & Ореол & Кадет & Драйв \\
\hline Без добрив (к) & 3,13 & 3,15 & 3,35 \\
\hline $\mathrm{N}_{30} \mathrm{P}_{40}$ & 3,28 & 3,45 & 3,45 \\
\hline $\mathrm{N}_{40} \mathrm{P}_{60}$ & 3,34 & 3,42 & 3,49 \\
\hline $\mathrm{N}_{60} \mathrm{P}_{80}$ & 3,41 & 3,40 & 3,58 \\
\hline $\mathrm{N}_{40} \mathrm{P}_{60} \mathrm{~K}_{60}$ & 3,37 & 3,45 & 3,53 \\
\hline $\mathrm{HIP}_{0,95}$ & для добрив-0,13 т/га; для гібридів $-0,11$ т/га; взаємодія - 0,23 т/га \\
\hline
\end{tabular}

Такі результати досліджень одержано В. М. Тоцьким, О. І. Поляковим, які зазначають, що найбільш чутливим до внесення добрив був середньоранній гібрид Запорізький 28. Практично всі дози мінеральних добрив забезпечили підвищення урожайності в межах 0,2 т/га. Середньостиглий гібрид Сава менше реагував на дози добрив, приріст врожаю насіння становив від 0,06 т/га у разі внесення $\mathrm{N}_{30} \mathrm{P}_{40}$ до 0,16 т/га на максимальному фоні удобрення $\mathrm{N}_{60} \mathrm{P}_{90}$ [16]. У дослідженнях Г. М. Господаренка зазначено, що соняшник $є$ калієфільною культурою. Однак, незважаючи на високу в ньому потребу, він середньо діє на рівень урожаю культури [4].

Отже, дослідження свідчать, що в середньому за гібридами, що вивчали в досліді приріст урожайності соняшнику залежно від дози мінеральних добрив, порівняно 3 контролем становив 0,18-0,25 т/га або 5,7-7,9\%. Верхнє значення цього показника в разі внесення $\mathrm{N}_{60} \mathrm{P}_{80}$, а нижнє - на фоні $\mathrm{N}_{30} \mathrm{P}_{40}$.

\section{Висновки}

В умовах Лівобережного Лісостепу України застосування різних доз мінеральних добрив забезпечило поліпшення поживного режим грунту, зокрема підвищення в ньому вмісту азоту на 11,2 мг/кг грунту, фосфору на 13,9, а калію на 18,6 мг/кг грунту. Внесення мінеральних добрив позитивно впливало на реалізацію продуктивного потенціалу гібридів соняшнику. Максимальну врожайність насіння гібридів соняшнику Ореол і Драйв (відповідно 3,41 і 3,58 т/га) одержано на фоні внесення $\mathrm{N}_{60} \mathrm{P}_{80}$. Гібрид Кадет практично не реагував на дози добрив та співвідношення в них елементів живлення. Тому в разі вирощування гібриду Кадет на чорноземних грунтах достатнім буде внесення мінеральних добрив у дозі $\mathrm{N}_{30} \mathrm{P}_{40}$.

Перспективи подальшої роботи в цьому напрямі. В подальшому доцільно дослідити вплив мінеральних добрив на водоспоживання та фітосанітарний стан посівів соняшнику.

\section{References}

1. Hanhur, V. V., Yeremko, L.S., \& Kocherha, A. A. (2020). Efektyvnist biostymuliatoriv za umovy peredposivnoi obrobky nasinnia soniashnyku. Visnyk Poltavskoi Derzhavnoi Ahrarnoi Akademii, 2, 36-42. doi: 10.31210/visnyk2020.03.04 [In Ukrainian].

2. Harbar, L. A., \& Horbatiuk, E. M. (2017). Osoblyvosti formuvannia produktyvnosti posiviv soniashnyku. Visnyk Poltavskoi Derzhavnoi Ahrarnoi Akademii, 1-2, 24-26. doi: 10.31210/visnyk2017.12.04 [In Ukrainian].

3. Horbatiuk, E. N., \& Harbar, L. A. (2017). Formyrovanye produktyvnosty posevov podsolnechnyka pry razlychnыkh uslovyiakh seva. Vestnyk Altaiskoho Hosudarstvennoho Ahrarnoho Unyversyteta, 8 (154), 53-58 [In Russian].

4. Hospodarenko, H. M. (2018). Systema zastosuvannia dobryv. Kyiv: TOV «SIK HRUP UKRAINA» [In Ukrainian].

5. Yeremenko, O. A. (2017). Produktyvnist soniashnyku zalezhno vid mineralnoho zhyvlennia ta peredposivnoi obrobky nasinnia za umov nedostatnoho zvolozhennia. Visnyk Poltavskoi Derzhavnoi Ahrarnoi Akademii, 3, 25-30. doi: 10.31210/visnyk2017.03.04 [In Ukrainian].

6. Yeshchenko, V. O., Kopytko, P. H., Kostohryz, P. V, \& Opryshko, V. P. (2014). Osnovy naukovykh 


\section{СІЛЬСЬКЕ ГОСПОДАРСТВО. РОСЛИННИЦТВО}

doslidzhen v ahronomii: Pidruchnyk. Vinnytsia: PP «TD «Edelveis i K»» [In Ukrainian].

7. Kaminskyi, V. F., \& Hanhur, V. V. (2018). Vynos pozhyvnykh rechovyn silskohospodarskymy kulturamy riznorotatsiinykh sivozmin livoberezhnoho Lisostepu. Zbirnyk Naukovykh Prats Natsionalnoho Naukovoho Tsentru «Instytut Zemlerobstva NAAN», 3, 3-10 [In Ukrainian].

8. Kovtun, T. V., Harbar, L. A., \& Knap, N. V. (2018). Formuvannia produktyvnosti hibrydiv soniashnyka za riznykh umov zhyvlennia. Naukovi Horyzonty, 7-8 (70), 125-130 [In Ukrainian].

9. Kokhan, A. V., Hanhur, V. V., Koretskyi, O. Ie., Len, O. I., \& Manko, L. M. (2015). Soniashnyk u sivozminakh livoberezhnoho Lisostepu Ukrainy. Visnyk Tsentru Naukovoho Zabezpechennia APV Kharkivskoi Oblasti, 18, 62-66 [In Ukrainian].

10. Lukhmenev, V. P. (2015). Vlyianye udobrenyi, funhytsydov y rehuliatorov rosta na produktyvnost podsolnechnyka. Yzvestyia Orenburhskoho Hosudarstvennoho Ahrarnoho Unyversyteta, 1(51), 41-46 [In Russian].

11. Masliiov, S. V., Yarchuk, I. I., Stepanov, V. V., \& Shkvar, S. V. (2019). Vplyv mineralnykh dobryv na rist, rozvytok ta vrozhainist soniashnyku $\mathrm{v}$ umovakh Luhanskoi oblasti. Visnyk Kharkivskoho Natsionalnoho Ahrarnoho Universytetu, 2, 56-64. doi: 10.35550/ISSN2413-7642.2019.02.06 [In Ukrainian].

12. Pinkovskyi, H. V., \& Mashchenko, Yu. V. (2019). Vplyv elementiv zhyvlennia na rodiuchist hruntu ta produktyvnist soniashnyku v Pravoberezhnomu Stepu Ukrainy. Tavriiskyi Naukovyi Visnyk, 107, 145-150. doi: 10.32851/2226-0099.2019.107.19

13. Sakharchuk, O. V., \& Harbar, L. A. (2018). Optymizatsiia umov zhyvlennia za vyroshchuvannia soniashnyku. Myronivskyi Visnyk, 7, 146-155. doi: 10.31073mvis201807-14 [In Ukrainian].

14. Tanchyk, S. P., Tsentylo, L. V., \& Tsiuk, O. A. (2019). Vplyv udobrennia ta obrobitku hruntu na vrozhainist kultur sivozminy. Visnyk Ahrarnoi Nauky, 8 (797), 11-16. doi: 10.31073/agrovisnyk201908-02 [In Ukrainian].

15. Totskyi, V. M. (2014). Vplyv systemy udobrennia ta osnovnoho obrobitku gruntu na formuvannia produktyvnosti soniashnyku. Naukovo-Tekhnichnyi Biuleten Instytutu Oliinykh Kultur NAAN, 20, 204-209 [In Ukrainian].

16. Totskyi, V. M., \& Poliakov, O. I. (2009). Vplyv mineralnykh dobryv na pokaznyky produktyvnosti ta yakosti nasinnia soniashnyku. Naukovo-Tekhnichnyi Biuleten Instytutu Oliinykh Kultur UAAN, 14, 232-237 [In Ukrainian].

17. Totskyi, V. M., \& Poliakov, O. I. (2007). Formuvannia vrozhainosti ta vykhid olii v zalezhnosti vid ahropryiomiv vyroshchuvannia soniashnyku v umovakh livoberezhnoho Lisostepu Ukrainy. NaukovoTekhnichnyi Biuleten Instytutu Oliinykh Kultur UAAN, 12, 245-249 [In Ukrainian].

18. Shevchenko, O. M., Onopriienko, V. P., \& Onychko, H. O. (2005). Vplyv system udobrennia na urozhainist ta hospodarski pokaznyky hibrydiv soniashnyku $\mathrm{v}$ umovakh pivnichno-skhidnoho rehionu Ukrainy. Visnyk Sumskoho Natsionalnoho Ahrarnoho Universytetu, 12, 55-58 [In Ukrainian].

19. Tsyliuryk, O. (2018). Dobryva dlia soniashnyku. Ahrobiznes Sohodni, 15-16, 88-91 [In Ukrainian].

20. Bailly, C., Benamar, A., Corbineau, F., \& Côme, D. (2000). Antioxidant systems in sunflower (Helianthus annuus L.) seeds as affected by priming. Seed Science Research, 10 (1), 35-42. doi: $10.1017 / \mathrm{s} 0960258500000040$

Стаття надійшла до редакції 20.02.2021 р.

Бібліографічний опис для цитування:

Гангур В. В., Космінський О. О., Міщенко О. В. Вплив мінеральних добрив на вміст поживних речовин у грунті та урожайність гібридів соняшнику різних груп стиглості. Вісник ПДАА. 2021. № 1. C. 116-121.

(с) Гангур Володимир Васильович, Космінський Олег Олегович, Міменко Олег Владиславович, 2021 